\title{
Rubella-specific IgM detected by an antibody capture assay/ELISA technique
}

\author{
JB KURTZ, A MALIC
}

From the Virology Laboratory and Public Health Laboratory, John Radcliffe Hospital, Oxford OX3 9DU

SUMMARY A sensitive method for detecting rubella IgM antibody, the first step of which is the attachment of the serum IgM to a solid phase, is described.

Specific IgM antibody was found in all 52 people with acquired rubella in the early convalescent period, in all 38 infants with congenital rubella examined in the first seven months of life, and in 23 of 26 people immunised one to four months before testing. Twenty-four of 44 rheumatoid factor-positive sera, however, gave false-positive readings. In routine use the test was economical of both reagents and time.

Detection of rubella IgM antibody is well established as a means of diagnosing recent infection in pregnant women or congenital infection in neonates. Most methods rely on a primary step to separate physically the IgM from the other serum immunoglobulins, for example, sucrose gradient centrifugation or gel filtration. ${ }^{1}$ Unfortunately, such methods of separating immunoglobulins lead to some loss, thus reducing the sensitivity of the test. More recently, radioimmunoassay and enzyme linked immunosorbant assay (ELISA) tests in which rubella antigen is bound to a solid phase have been used, ${ }^{2}$ but when whole serum is added to a solid phase antigen, competition between antibodies of the various classes may cause false-negative results.

In 1979 Duermeyer et al $^{3}$ described a technique, the antibody capture assay, in which human IgM is selectively attached to the solid phase by anti-human IgM (anti- $\mu$ chain) antibody. When antigen is then added it will bind to any of its antibody present in the IgM fraction of the serum being tested. Finally, the presence of the bound antigen is detected by antibody, labelled with an enzyme or radioisotope.

We report here the antibody capture assay using an enzyme linked indicator system for detecting rubella IgM antibody.

\section{Material and methods}

TEST SERA

Eighty-three sera were tested from 52 cases of clinical rubella, confirmed in the laboratory by seroconversion or a greater than fourfold rise in antibody titre. Thirty-five sera were tested from 28 infants

Accepted for publication 13 May 1981 with congenital rubella, defined as a child having one or more defects associated with the syndrome ${ }^{4}$ and from whom the virus had been isolated or whose antibody persisted for more than 10 months from birth. Sera from 27 previously rubella seronegative women who had been recently immunised and sera from 260 women attending the antenatal clinic whœ had not been exposed to rubella, and who denies any recent rash or illness, were examined. Tö investigate the effect of rheumatoid factor (RF) on the test, 44 RF-positive sera were also tested.

PREPARATION OF THE ENZYME CONJUGATE The periodate method for conjugating immunoglobulin and horseradish peroxidase was based on that of Nakane and Kawaoi (1974)..$^{5}$ The immunoglobulin was prepared from the serum of a rabbit immunised with rubella virus grown in RK 13 cells. The serum was fractionated on a QAE-Sephadex A-50 column, $10 \mathrm{~cm} \times 1 \mathrm{~cm}$ (Pharmacia Ltd), with $0 \cdot 1 M$ ethylene diamine-acetic acid buffer $\mathrm{pH} 7 \cdot 0$. The protein concentration of the immunoglobulin was adjusted to $4 \mathrm{mg} / \mathrm{ml}$ and it was then dialysed overnight against $0.01 M$ sodium carbonate buffer pH 9.5.

Horseradish peroxidase $(4 \mathrm{mg})$ (Sigma Chemical Co) was dissolved in $1 \mathrm{ml}$ distilled water and $0.2 \mathrm{ml}$ freshly prepared $0.1 \mathrm{M}$ sodium periodate added. This mixture was stirred for $20 \mathrm{~min}$ and then dialysed overnight against $1 \mathrm{mM}$ sodium acetate buffer $\mathrm{pH} \mathrm{4.4}$. The $\mathrm{pH}$ of the mixture was raised to 9.5 with $0.2 \mathrm{ml}$ of $0.2 M$ sodium carbonate buffer pH 9.5. One $\mathrm{ml}$ of the immunoglobulin preparation was added and stirred for two hours at room temperature, then $0.1 \mathrm{ml}$ of a solution of sodium borohydride $(4 \mathrm{mg} / \mathrm{ml}$ distilled water) was added to 
break down any remaining free enzyme. After standing for two hours at $+4^{\circ} \mathrm{C}$ the conjugate was dialysed overnight against $0 \cdot 1 M$ borate buffer $\mathrm{pH} 7.4$ and then diluted with an equal volume of $60 \%$ glycerol in borate buffer. It was stored at $+4^{\circ} \mathrm{C}$.

PREPARATION OF THE SOLID PHASE

The wells of polystyrene micro-ELISA plates (Dynatech Laboratories) were coated with an anti- $\mu$ chain serum (Dako Immunoglobulins a/s) by adding to each well $0.2 \mathrm{ml}$ of a $1 / 500$ dilution of the serum in $0.05 M$ carbonate/bicarbonate buffer pH 9.6. The plates were then kept at room temperature for $48 \mathrm{~h}$ and before use shaken dry and rinsed once with phosphate buffer saline (Dulbecco A) supplemented with $0.05 \%$ Tween 20 and $0.1 \%$ bovine serum albumen (PBSTA).

\section{TEST PROCEDURE}

Sera to be tested were diluted $1 / 100$ in PBSTA and $0.2 \mathrm{ml}$ aliquots added to duplicate anti- $\mu$ treated wells of a micro-ELISA plate. The plate was held at $37^{\circ} \mathrm{C}$ for two hours. After washing with PBSTA five times, $0.2 \mathrm{ml}$ of a $1 / 20$ dilution of rubella antigen prepared in BHK 21 cells (Public Health Laboratory, Division of Microbiological Reagents and Quality Control) in PBSTA was added to each well and the plate was held at $+4^{\circ} \mathrm{C}$ for $16-24 \mathrm{~h}$. The plate was washed five times with PBSTA, after which $0.2 \mathrm{ml}$ of the enzyme-conjugate diluted $1 / 500$ in PBSTA was added to each well and incubated at $37^{\circ} \mathrm{C}$ for two hours. The washing was repeated and then $0.1 \mathrm{ml}$ of the freshly prepared substrate $(0.4 \mathrm{mg} / \mathrm{ml} \mathrm{O}$-phenylenediamine and $0.2 \mathrm{mg} / \mathrm{ml}$ urea peroxide in $0.075 \mathrm{M}$ citrate phosphate buffer $\mathrm{pH}$ 5.0) was added to each well. The plate was kept in the dark at room temperature for $25 \mathrm{~min}$ and then $0.025 \mathrm{ml}$ of $4 \mathrm{~N}$ sulphuric acid was added to each well to stop the enzyme reaction. The optical density (OD) of the contents of each well was read in a Vitatron photometer with a $492 \mathrm{~nm}$ interference filter.

A reference rubella IgM-positive serum and a panel of four sera negative for rubella IgM but positive for rubella IgG antibody were included in each test. Results were expressed as the ratio-OD test serum $(t)$ :mean $O D$ of reference negative sera $(\mathrm{N})$.

A ratio $(t / N)$ greater than $2 \cdot 1$ was considered to indicate a positive result. ${ }^{6}$

\section{AGGREGATED HUMAN IMMUNOGLOBULIN}

Human normal immunoglobulin $(250 \mathrm{mg}$ ) (Blood Products Laboratory, Elstree, Herts) diluted with an equal volume $0.01 M$ phosphate-buffered saline (PBS) was heated at $63^{\circ} \mathrm{C}$ for $10 \mathrm{~min}$ and further heated at $72^{\circ} \mathrm{C}$ for $10 \mathrm{~min}$. The precipitate obtained was washed four times in the diluent. It was then mixed with $1 M$ glycine to give a $1 / 4$ dilution and held at $+4^{\circ} \mathrm{C}$ overnight. After three more washes in $0.01 M$ PBS it was dispensed in aliquots and stored at $-20^{\circ} \mathrm{C}$. For use, a $1 / 2$ dilution of the aggregated immunoglobulin in 0.01 $M$ PBS was mixed with an equal volume of serum diluted $1 / 20$. The mixture was shaken for one hour at $37^{\circ} \mathrm{C}$ and then held at $+4^{\circ} \mathrm{C}$ overnight. The supernatant serum was then ready for testing.

\section{RHEUMATOID FACTOR (RF) TESTS}

Sera were tested by a latex slide test (Ortho Diagnostics, Beerse, Belgium) at a dilution of $1 / 20$. They were also titrated from a dilution of $1 / 2$ in the Rose-Waaler test, ${ }^{7}$ titres of $\geqslant 1 / 32$ were regarded as significant.

\section{Results}

\section{SENSITIVITY}

Figure 1 shows the declining OD readings obtained when the reference rubella IgM-positive serumhaemagglutination inhibition (HI) titre of the whole serum $1 / 320$, HI titre after absorption with staphylococcal protein $A^{8} 1 / 80$ - was serially diluted in a rubella IgM-negative serum. The sensitivity of the test is limited to the point where the curve obtained crosses the cut-off line which is $2.1 \times$ the mean OD of the panel of negative sera tested; in this experiment $2 \cdot 1 \times 0.14=0.29$. Specific IgM antibody was detected in a thirtyfold dilution of the serum.

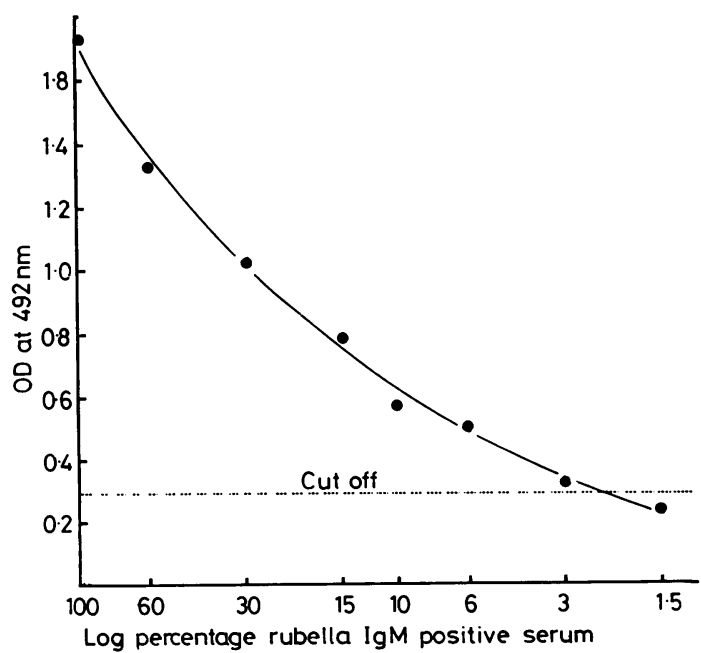

Fig. 1 OD readings against dilutions of a rubella IgM-positive serum in a rubella IgM-negative serum. 
ROUTINE ANTENATAL SERA

There was no reason to suspect clinically that any of the expectant mothers whose antenatal sera were being tested had, or had recently had, rubella. The 260 sera were tested at different times and with two different enzyme conjugate preparations. None of the sera gave a positive result, the $t / N$ ratios all being $<2 \cdot 1$. The 153 sera tested with the first conjugate preparation gave a mean $O D$ of 0.16 (range $0 \cdot 10-0 \cdot 24$ ). The mean $O D$ readings of the panel of negative sera included in each batch of tests with this conjugate ranged between 0.15 and $\mathbf{0} \cdot 17$. The second conjugate gave lower background $O D$ readings and the mean OD for the 107 sera examined with it was $0 \cdot 11$ (range $0 \cdot 07-0 \cdot 19$ ). The negative panel mean $O D$ results ranged between 0.09 and 0.11 with the second conjugation.

\section{ACQUIRED RUBELLA INFECTION}

Eighty-three sera from 52 cases of acquired rubella were all negative when tested for rheumatoid factor. Figure 2 shows the results of rubella IgM tests in relation to the date of onset of the rash. It can be

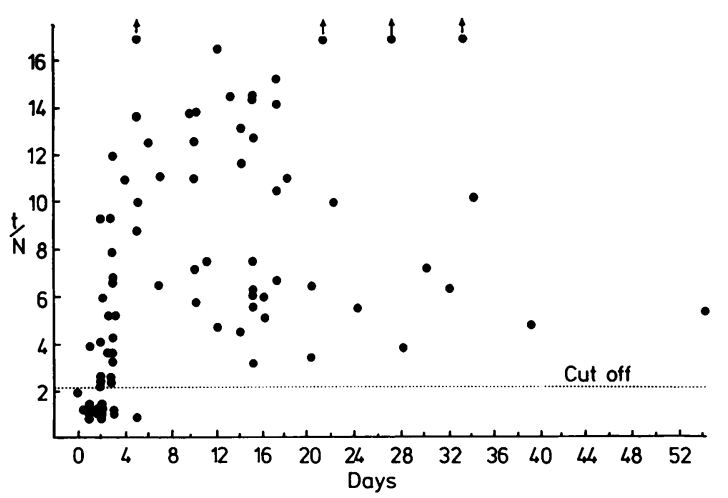

Fig. 2 Rubella IgM antibody, expressed as the ratio $O D$ test: $O D$ negative controls $(t / N)$ against daysafter rash.

seen that on the day of, or following the rash, only one of the seven sera tested had rubella IgM antibody and on the second day five out of 12 were positive, with one borderline result. No negative result was detected after the fifth day in any of the sera tested and rubella-specific IgM could still be detected in a serum which had been taken 54 days after the onset of the rash.

\section{CONGENITAL RUBELLA}

Thirty-five sera were tested from 28 infants with congenital rubella. Figure 3 shows these results. All of the 29 sera taken before the seventh month of

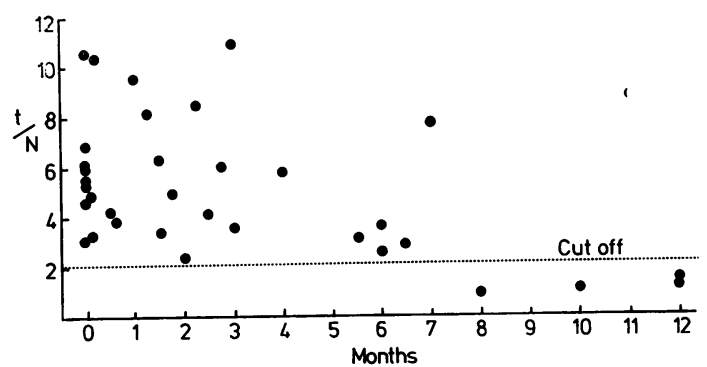

Fig. 3 Rubella IgM antibody, expressed as the ratio $O D$ test: $O D$ negative controls $(t / N)$ against age.

life were positive but of the six sera taken at or after 7 months, only one (taken at 11 months of age) had detectable rubella IgM antibody. None of these 35 sera was positive for rheumatoid factor.

\section{VACCINATION}

A serum sample was taken from each of 27 people who had been seronegative, between one and four months after they had been vaccinated. All of the 21 sera taken in the second month were found to have rubella IgM antibody. Fourteen of these sera were available for testing for rubella IgM antibody 8 by the $\mathrm{Hl}$ test after absorption with staphylococcal protein $\mathbf{A},{ }^{8}$ and only seven were found to be positive by this method. Later, in the third month, two of three sera gave a positive result for the IgM antibody in the ELISA test but neither was positive when tested by the $\mathrm{HI} /$ staphylococcal protein $\mathrm{A}$ method. Four months after vaccination only one of three gave a weak positive result in the ELISA test. The 24 sera that gave rubella IgM-positive results in the ELISA test were examined for RF but none was found to be positive.

\section{RHEUMATOID FACTOR}

The 44 sera were all positive by the latex slide test for RF. Twenty-eight of these sera, which all contained rubella IgG but not IgM antibody when tested by $\mathrm{HI} /$ staphylococcal protein $A$ method, ${ }^{8}$ gave positive results in the rubella IgM ELISA test. In each case after treatment of the serum with aggregated IgG the RF test was negative. This treatment also reduced the $t / \mathrm{N}$ ratio in the rubella IgM ELISA test to below the cut-off value. Aggregated IgG treatment of sera from convalescing rubella patients, however, did not alter their $\mathrm{t} / \mathrm{N}$ ratios.

When these 44 sera were titrated in the RoseWaaler (R-W) test, however, only 30 were RFpositive, the reciprocal titres ranging from $1 / 32$ to 1/4096. Of the 14 latex test-positive, R-W test- 
negative sera, 13 were negative in the rubella IgM ELISA test. In contrast, of the 30 sera RF-positive by both tests, 27 were also positive in the ELISA test and the three rubella IgM test-negative sera had low titres in the R-W test (one of 32, two of 64). Sera that are positive for RF by the R-W test are therefore especially liable to be falsely positive in the rubella IgM ELISA test described.

Further tests on these sera revealed an unexpected cause of false results. Positive results with RFcontaining sera were given even when the rubella antigen was omitted. Direct attachment of rabbit IgG in the conjugate to the RF fixed to the plate gave a false-positive result.

\section{Discussion}

The results given above demonstrate the sensitivity of this test for detecting IgM antibody in acquired rubella, congenital rubella and after immunisation. They support the preliminary findings of Diment and Chantler. ${ }^{9}$

Mortimer et al $^{10}$ report an antibody capture assay for rubella IgM antibody using a radioimmunoassay detector system. One hundred and ten of the sera tested by our ELISA method were also tested by that radioimmunoassay technique and the results showed a similar order of sensitivity (unpublished observations).

The antibody capture assay has advantages over other methods of detecting IgM specific antibody. No pretreatment of the serum is necessary. The number of sera that can be tested at any one time is not limited by centrifuge capacity or the time taken for gel filtration; nor is there a loss of IgM. Advantages of the ELISA system compared to radioimmunoassay are that the conjugate is more stable. We have used the two enzyme-linked conjugates described above for nine months without any loss of titre. There are no radiation hazards and an expensive gamma-counter is not required.

A disadvantage is that the presence of rheumatoid factor, an IgM antibody to the Fc portion of altered IgG, may cause false-positive results. The RF can attach the patient's IgG rubella antibody to the plate, or, as we have shown, it can react with altered $\mathrm{IgG}$ in the conjugate. This latter problem can be overcome by removing altered IgG from the con- jugate, ${ }^{11}$ or by conjugating only the Fab 2 portion. ${ }^{3}$ Another method of ensuring specificity is to perform a duplicate test on each serum, omitting the addition of antigen. In practice, we screen all sera giving rubella IgM-positive results for RF.

The application of this test for IgM antibody detection not only to rubella but also to many other infectious agents should greatly improve the scope of the diagnostic laboratory.

We thank Dr JE Cradock-Watson and Dr MS Shafi for kindly supplying some of the sera tested.

\section{References}

${ }^{1}$ Morgan-Capner P, Davies E, Pattison JR. Rubellaspecific IgM detection using Sephacryl S-300 gel filtration. J Clin Pathol 1980;33:1082-5.

2 Cradock-Watson JE, Ridehalgh MKS, Pattison JR, Anderson MJ, Kangro HO. Comparison of immunofluorescence and radioimmunoassay for detecting IgM antibody in infants with the congenital rubella syndrome. J Hyg (Camb) 1979;83:413-23.

${ }^{3}$ Duermeyer W, Wielaard F, Van der Veen J. A new principle for the detection of specific IgM antibodies applied to an elisa for hepatitis A. J Med Virol 1979; 4:25-32.

${ }^{4}$ Hanshaw JB, Dudgeon JA. Viral diseases of the foetus and newborn. Philadelphia: WB Saunders Co, 1978:39-44.

${ }^{5}$ Nakane PK, Kawaoi A. Peroxidase-labelled antibody. A new method of conjugation. J Histochem Cytochem 1974;22:1084-91.

${ }^{6}$ Roggendorf M, Frösner GG, Deinhardt F, Scheid R. Comparison of solid phase test systems for demonstrating antibodies against hepatitis A virus (anti-Hav) of the IgM class. J Med Virol 1980;5:47-62.

7 Bird GWG, Wigham J. Agglutination and agglutination inhibition. In: Thompson RA, ed. Techniques in immunology. Oxford: Blackwell Scientific Publications, 1981.

8 Pattison JR, ed. Laboratory investigation of rubella. (Public Health Laboratory Service Monograph Series No 16.) London: HMSO, 1981.

9 Diment JA, Chantler S. Enzyme immunoassay for detection of rubella specific IgM antibody. Lancet 1981; i:394-5.

${ }^{10}$ Mortimer PP, Tedder RS, Hambling MH, Shafi MS, Burkhardt F, Schilt U. Antibody capture radioimmunoassay for anti-rubella IgM. J Hyg (Camb) 1981; 86:139-53.

11 Smith AM, Tedder RS. Development of an enzyme-linked immunosorbant assay (elisa) for hepatitis B e antigen and antibody. J Virol Methods 1981;3:1-11.

Requests for reprints to: Dr JB Kurtz, Department of Virology, John Radcliffe Hospital, Headington, Oxford OX3 9DU, England. 